\title{
PENGARUH KOMUNIKASI DAN DISIPLIN KERJA TERHADAP KINERJA KARYAWAN PADA CAFÉ KOPI MASSA KOKTONG LIM MING PEMATANGSIANTAR
}

\author{
Oleh: \\ Friska Purnamasari Sihombing \\ S1 Manajemen \\ Darwin Lie, Marisi Butarbutar, Stefi Inggrid Thressa
}

Abstraksi

Adapun rumusan masalah penelitian ini adalah bagaimana pengaruh komunikasi dan disiplin kerja terhadap kinerja karyawan pada Café Kopi Massa Koktong LIM MING Pematangsiantar secara simultan maupun parsial. Penelitian ini dilakukan dengan menggunakan desain penelitian lapangan dan kepustakaan. Adapun populasi yang digunakan penulis dalam penelitian ini adalah sebanyak 30 responden yaitu karyawan pada Café Kopi Massa Koktong LIM MING Pematangsiantar. Jenis data yang digunakan adalah data kualitatif dan data kuantitatif. Sumber data yang digunakan adalah data primer dan data sekunder. Pengumpulan data dilakukan dengan kuesioner, wawancara dan dokumentasi. Teknik analisis yang digunakan ialah regresi linier berganda, koefisien korelasi dan determinasi serta pengujian hipotesis dengan uji $\mathrm{F}$ dan uji t.

Hasil penelitian dapat disimpulkan sebagai berikut: 1. Komunikasi dan disiplin kerja sudah baik serta kinerja karyawan cukup baik. 2. Hasil analisis regresi adalah $\hat{Y}=16,059+0,202 X_{1}+0,346 X_{2}$, artinya komunikasi dan disiplin kerja berpengaruh positif terhadap kinerja karyawan. 3. Hasil analisis korelasi diperoleh nilai $r=0,778$ artinya hubungan komunikasi, disiplin kerja dengan kinerja karyawan kuat dan positif. Tinggi rendahnya kinerja karyawan dapat dijelaskan oleh komunikasi dan disiplin kerja sebesar 60,6\%. 4. Hipotesis penelitian $\mathrm{H}_{0}$ ditolak, artinya komunikasi dan disiplin kerja berpengaruh positif dan signifikan terhadap kinerja karyawan pada Café Kopi Massa Koktong LIM MING Pematangsiantar secara simultan maupun parsial.

Adapun saran dari penelitian ini adalah untuk meningkatkan komunikasi, sebaiknya manajer menerapkan komunikasi informal kepada karyawan dan menyediakan kotak saran untuk pelanggan. Untuk meningkatkan disiplin kerja, sebaiknya manajer menyediakan mesin absen finger scan dan membuat SOP (Standart Operational Procedure) yang baik. Untuk meningkatkan kinerja karyawan, sebaiknya manajer memberikan pelatihan kepada karyawan.

Kata kunci: Komunikasi, Disiplin kerja, dan Kinerja Karyawan.

\section{Abstraction}

As for this research problem formula is how communication and discipline of work influence to employees performance at Café Coffee Massa Koktong LIM MING Pematangsiantar simultaneously or partially. This research was conducted using field research design and literature. The population used in this study is the author of 30 respondents are employees at Café Coffee Massa Koktong LIM MING Pematangsiantar. The data used is the quantitative and qualitative data. Source data used are primary data and secondary data. Data was collected through questionnaires, interviews and documentation. The analysis technique used is multiple linear regression, correlation and determination coefficient and hypothesis testing by $F$ test and t test.

It can be concluded as follows: 1. Communication and work discipline are good as well as the employee's performance is quite good. 2. Results of regression analysis is $Y=16,059+0,202 X_{1}+0,346 X_{2}$, means of communication and discipline positive effect on employee performance. 3. The results of the analysis obtained correlation $r=0,778$ means of communication links, work discipline with a strong performance and positive employee. The level of employee performance can be explained by communication and discipline of 60,6\%. 4 . Research hypothesis $H_{0}$ is rejected, means of communication and work discipline positive and significant effect on the performance of employees at Café Coffee Massa Koktong LIM MING Pematangsiantar simultaneously or partially.

The suggestion of this research is to improve communication, managers should implement informal communication to employees and provide a suggestion box for customers. To improve work discipline, managers should provide the finger scan engine's absence and make a SOP (Standard Operational Procedure) good. To improve the performance of employees, managers should provide training to employees.

Keywords: Communication, Work Discipline and Employee Performance.

\section{A. PENDAhuluan}

1.Latar Belakang Masalah

Café Kopi Massa Koktong LIM MING Pematangsiantar merupakan perusahaan yang bergerak dalam bidang jasa pelayanan hybrid, yaitu penawaran yang terdiri dari jasa dan produk dalam skala yang sama.

Kinerja adalah salah satu tolak ukur yang mengukur keberhasilan seseorang dalam melakukan tugas, tindakan atau aktivitas pada suatu periode 
dengan referensi pada sejumlah standar. Kinerja karyawan menunjukkan seberapa banyak karyawan memberi kontribusi kepada organisasi, yang diantaranya adalah kuantitas, kualitas, ketepatan waktu, kehadiran di tempat kerja dan sikap kooperatif. Berikut adalah fenomena kinerja karyawan yang ada pada Café Kopi Massa Koktong LIM MING Pematangsiantar.

Tabel 1

Dimensi Kinerja Karyawan pada Café Kopi Massa Koktong

LIM MING Pematangsiantar

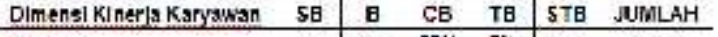

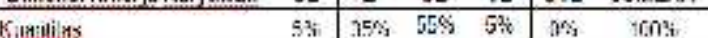

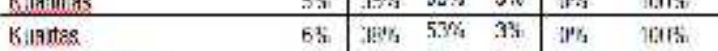

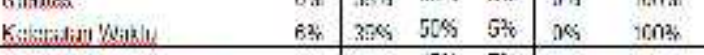

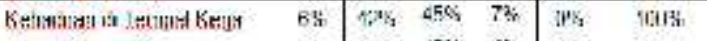

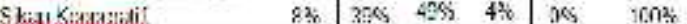

Sumber: hasil wawancara dengan Manajer Café (Agustus, 2016)

Pada tabel 1 di atas, diketahui bahwa kinerja karyawan pada Café Kopi Massa Koktong LIM MING Pematangsiantar masih belum optimal, hal ini dapat dilihat dari adanya persentase yang cukup baik dan tidak baik pada tabel di atas. Fenomena kinerja karyawan Café Kopi Massa Koktong LIM MING Pematangsiantar menunjukkan adanya kinerja yang tidak optimal seperti jumlah karyawan yang kurang memadai jika dibandingkan dengan jumlah pekerjaan yang secara langsung akan berdampak terhadap hasil kerja karyawan dalam melayani pelanggan, adanya karyawan yang terlambat masuk kerja, ketidakhadiran karyawan tanpa surat keterangan, dan terjadinya ketidakharmonisan komunikasi antar karyawan.

Komunikasi adalah hal yang terpenting dalam suatu organisasi yang merupakan suatu kegiatan penyampaian pesan secara intern di dalam organisasi. Komunikasi akan berjalan lancar dengan baik apabila arus informasi dalam organisasi tidak menghadapi hambatan. Faktor-faktor yang mempengaruhi komunikasi diantaranya adanya komunikator, pesan, komunikan, media, dan efek. Adapun fenomena komunikasi yang terjadi pada Café Kopi Massa Koktong LIM MING Pematangsiantar adalah diadakannya rapat yang mempertemukan manajer dengan karyawan untuk membahas kesulitan karyawan dalam bekerja dan hasil kerja yang diharapkan. Kemudian hubungan antar karyawan kurang harmonis yang terlihat dari tutur kata kasar karyawan yang dapat menyebabkan perselisihan dengan rekan kerjanya. Meskipun demikian, para karyawan masih dapat melayani pelanggan dengan menggunakan tutur kata yang sopan.

Disiplin kerja adalah suatu aktivitas yang menjadi alat komunikasi untuk mengubah dan memperbaiki suatu perilaku melalui tindakan disipliner yang positif. Dengan adanya disiplin kerja, suatu organisasi dapat menggapai tujuan dari program kerja yang sedang dikerjakan. Disiplin kerja yang baik dapat dilihat dari beberapa indikator seperti frekuensi kehadiran, tingkat kewaspadaan, ketaatan pada standar kerja, ketaatan pada peraturan kerja, dan etika kerja. Pada Café Kopi Massa Koktong LIM MING Pematangsiantar masih terdapat karyawan yang sering tidak hadir, kewaspadaan karyawan dalam meletakkan hidangan di meja pelanggan, tidak menyapa tamu karena sibuk dengan ponselnya, tidak menggunakan seragam kerja, dan berbicara dengan kata-kata yang kurang sopan kepada rekan kerjanya serta pengenaan sanksi disiplin yang kurang efektif.

\section{Rumusan Masalah}

a. Bagaimana gambaran komunikasi, disiplin kerja, dan kinerja karyawan pada Café Kopi Massa Koktong LIM MING Pematangsiantar.

b. Bagaimana pengaruh komunikasi dan disiplin kerja terhadap kinerja karyawan Café Kopi Massa Koktong LIM MING Pematangsiantar baik secara simultan maupun parsial.

\section{Tujuan Penelitian}

a. Untuk mengetahui gambaran komunikasi, disiplin kerja, dan kinerja karyawan pada Café Kopi Massa Koktong LIM MING Pematangsiantar.

b. Untuk mengetahui pengaruh komunikasi dan disiplin kerja terhadap kinerja karyawan pada Café Kopi Massa Koktong LIM MING Pematangsiantar baik secara simultan maupun parsial.

\section{Metode Penelitian}

Objek penelitian adalah Café Kopi Massa Koktong LIM MING Pematangsiantar yang terletak di Jalan M.H. Sitorus No. 3A-B, Kelurahan Teladan, Kecamatan Siantar Barat, Kota Pematangsiantar, Sumatera Utara. Populasi adalah semua karyawan Café Kopi Massa Koktong LIM MING Pematangsiantar sebanyak 30 orang. Oleh karena subjek yang ada kurang dari 100, maka penelitian ini menggunakan sampel jenuh dimana semua subjek yang ada diteliti.

Adapun desain penelitian yang digunakan dalam penulisan skripsi ini adalah Penelitian Kepustakaan (Library Research) dan Penelitian Lapangan (Field Research). Teknik pengumpulan data yang dilakukan penulis dalam penelitian ini adalah berupa Kuesioner, Wawancara dan Dokumentasi. Jenis data yang digunakan dalam penelitian ini adalah jenis data kualitatif dan data kuantitatif. Hasil data yang diperoleh dari lapangan akan dianalisis secara deskriptif baik bersifat kualitatif dan kuantitatif.

\section{B. LANDASAN TEORI}

1. Manajemen Sumber Daya Manusia

Menurut Sutrisno (2011:5), manajemen sumber daya manusia merupakan bidang strategis dari organisasi yang harus dipandang sebagai perluasan dari pandangan tradisional untuk mengelola orang secara efektif dan untuk itu membutuhkan pengetahuan tentang perilaku manusia dan kemampuan mengelolanya. Kemudian, pengertian manajemen sumber daya manusia yang 
dikemukakan Mondy (2008:4) merupakan pemanfaatan sejumlah individu untuk mencapai tujuan-tujuan organisasi. Berdasarkan beberapa pengertian di atas, maka dapat disimpulkan bahwa manajemen sumber daya manusia adalah suatu bidang strategis dari organisasi dengan memanfaatkan sumber daya manusia secara efektif dan efisien tujuan organisasi meliputi segi perencanaan, pengorganisasian, pelaksanaan dan pengendalian.

\section{Komunikasi}

Menurut Robbins dan Timothy (2008:5), komunikasi adalah perpindahan (transfer) makna diantara anggota-anggota suatu perusahaan, sebab tidak ada kelompok yang dapat eksis tanpa komunikasi. Sedangkan menurut Davis (2008:150), komunikasi merupakan cara menyampaikan gagasan, fakta, dan pikiran serta nilai kepada orang lain Berdasarkan pengertian para ahli di atas, maka penulis mengambil kesimpulan bahwa komunikasi adalah perpindahan (transfer) makna antar manusia yang tidak tergantung pada teknologi, melainkan kekuatan dalam diri untuk mencari cara menyampaikan gagasan, fakta, pikiran maupun nilai agar mudah dimengerti oleh orang lain.

Menurut Redfield dalam Wursanto (2005:157), komunikasi megandung lima unsur yang mempengaruhi terjadinya komunikasi, yaitu: komunikator (communicator), menyampaikan berita, berita-berita yang disampaikan (messages), komunikan (communicatee), tanggapan atau reaksi (response), dalam bentuk jawaban atau reaksi. Sedangkan menurut Subarna (2003:19), terdapat 5 (lima) faktor-faktor yang mempengaruhi komunikasi antara lain: komunikator, pesan, komunikan, saluran/media, dan efek. Berdasarkan penjelasan di atas dapat diambil kesimpulan bahwa terdapat banyak hal yang dapat mempengaruhi dan menjadi acuan terjadinya sebuah komunikasi. Unsur dari komunikasi merupakan satu kesatuan yang utuh dan bulat, dalam arti apabila satu faktor tidak ada, maka komunikasi tidak akan terjadi. Dengan demikian, keberhasilan dari semua faktor akan menimbulkan komunikasi yang baik.

\section{Disiplin Kerja}

Menurut Zainal (2009:599), disiplin kerja adalah suatu alat yang digunakan para manajer untuk berkomunikasi dengan karyawan agar mereka bersedia untuk mengubah suatu perilaku serta sebagai suatu upaya untuk meningkatkan kesadaran dan kesediaan seseorang mentaati semua peraturan perusahaan dan norma-norma sosial yang berlaku. Sedangkan menurut Handoko (2001:209), disiplin kerja adalah suatu aktivitas yang dilakukan untuk memperbaiki kegiatan di waktu yang akan datang dan bukan menghukum kegiatan di masa lalu melalui tindakan pendisiplinan yang positif yakni bersifat mendidik dan mengoreksi, bukan tindakan pendisiplinan yang negatif seperti atasan menjatuhkan karyawan yang berbuat salah. Berdasarkan definisi-definisi di atas, dapat diambil kesimpulan bahwa disiplin kerja adalah suatu aktivitas yang menjadi alat komunikasi untuk mengubah dan memperbaiki suatu perilaku melalui tindakan disipliner yang positif.

Menurut Sastrohadiwiryo (2002:291) terdapat beberapa dimensi disiplin kerja antara lain: frekuensi kehadiran, tingkat kewaspadaan, ketaatan pada standar kerja, ketaatan pada peraturan kerja, dan etika kerja. Sedangkan menurut Tulus (2004:33), ada beberapa indikator sikap disiplin yang dilakukan dalam pekerjaan, yaitu: disiplin terhadap peraturan, yaitu tatanan dan sikap taat pada norma-norma, disiplin terhadap diri sendiri, yaitu suatu sikap kesadaran dan perilaku diri, disiplin terhadap kualitas, yaitu pemenuhan kualitas kerja, disiplin terhadap prioritas kerja, yaitu sasaran utama dalam bekerja, disiplin terhadap prosedur, yaitu penggunaan cara dan proses dalam bekerja. Berdasarkan penjelasan di atas, penulis menyimpulkan bahwa setiap sikap dan perilaku yang terdapat didalam indikator disiplin kerja merupakan suatu alat yang dapat dipergunakan untuk mengukur tingkat kedisiplinan pegawai.

\section{Kinerja Karyawan}

Menurut As'ad (2003:6), kinerja merupakan ukuran sejauh mana keberhasilan seseorang dalam melakukan tugas pekerjaannya. Sedangkan menurut Zainal (2009:447), kinerja merupakan suatu istilah secara umum yang digunakan untuk sebagian atau seluruh tindakan atau aktivitas dari suatu organisasi pada suatu periode dengan referensi pada sejumlah standar seperti biaya-biaya masa lalu atau yang diproyeksikan, dengan dasar efisiensi, pertanggungjawaban atau akuntabilitas manjemen dan semacamnya. Berdasarkan pengertian para ahli di atas, maka penulis mengambil kesimpulan bahwa kinerja adalah salah satu tolak ukur yang mengukur keberhasilan seseorang dalam melakukan tugas, tindakan atau aktivitas pada suatu periode dengan referensi pada sejumlah standar.

Menurut Stoner dan Freeman dalam Dharma (2001:554) kinerja karyawan dinilai dari : kuantitas kerja, kualitas kerja, kreativitas, pengetahuan mengenai pekerjaan, kerjasama, inisiatif, ketergantungan, dan kualitas pribadi. Menurut Zainal (2009:447), penilaian kinerja dapat dimanfaatkan oleh manajemen untuk :

a. Mengelola operasi organisasi secara efektif dan efisien melalui pemotivasian karyawan secara maksimum

b. Membantu pengambilan keputusan yang bersangkutan dengan karyawannya seperti promosi, pemberhentian, mutasi.

c. Mengidentifikasi kebutuhan pelatihan dan pengembangan karyawan dan untuk menyediakan kriteria seleksi dan evaluasi program pelatihan karyawan.

d. Menyediakan umpan balik bagi karyawan mengenai bagaimana atasan mereka menilai kinerja mereka.

e. Menyediakan suatu dasar bagi distribusi penghargaan. 
Berdasarkan penjelasan di atas dapat disimpulkan bahwa peningkatan kinerja karyawan dapat diketahui dengan melakukan penilaian kinerja terlebih dahulu secara adil dan jujur, sehingga manfaat dari penilaian kinerja tersebut dapat dirasakan oleh perusahaan.

\section{PEMBAHASAN}

\section{Analisa}

\section{a. Deskriptif Kualitatif}

Analisis deskriptif kuantitatif dimaksudkan untuk mendapatkan gambaran atau deskripsi mengenai tanggapan dari karyawan mengenai Pengaruh Komunikasi dan Disiplin kerja terhadap Kinerja Karyawan pada Café Kopi Massa Koktong LIM MING Pematangsiantar. Adapun penetapan kriteria nilai rata-rata jawaban dari responden tersebut dimasukkan kedalam kelas-kelas interval dimana penentuan intervalnya memakai rumus sebagai berikut:

Interval Kelas $=\underline{\text { Nilai Tertinggi }- \text { Nilai Terendah }}$

$$
\text { Jumlah Kelas }
$$

Dari rumus di atas dapat diperoleh interval kelas 0,8 sehingga berlaku ketentuan indikator dengan hasil sebagai berikut:

Tabel 2

Nilai Interval dan Indikator Jawaban Responden

\begin{tabular}{|c|c|c|c|}
\hline $\begin{array}{c}\text { Nilai } \\
\text { Interval }\end{array}$ & \multicolumn{3}{|c|}{ Indikator } \\
\cline { 2 - 4 } & Komunikasi & Disiplin kerja & Kinerja Kerja \\
\hline $1,00-1,80$ & Sangat Tidak Baik & $\begin{array}{c}\text { Sangat Tidak } \\
\text { Baik }\end{array}$ & $\begin{array}{c}\text { Sangat Tidak } \\
\text { Baik }\end{array}$ \\
\hline $1,81-2,60$ & Tidak Baik & Tidak Baik & Tidak Baik \\
\hline $2,61-3,40$ & Cukup Baik & Cukup Baik & Cukup Baik \\
\hline $3,41-4,20$ & Baik & Baik & Baik \\
\hline $4,21-5.00$ & Sangat Baik & Sangat Baik & Sangat Baik \\
\hline
\end{tabular}

Sumber : hasil pengolahan data

\section{1) Gambaran Komunikasi Pada Café Kopi} Massa Koktong LIM MING Pematangsiantar

Dari hasil analisa, dapat dilihat bahwa sebagian besar responden berpendapat komunikasi pada tahap yang sangat baik. Untuk dimensi komunikator pada indikator manajer dapat berkomunikasi dengan baik kepada anda berada pada rata-rata 3,57 dengan kriteria jawaban baik, hal ini disebabkan hanya sesekali manajer dapat berinteraksi dengan karyawan. Pada indikator anda dapat berkomunikasi dengan baik kepada manajer dan pelanggan berada pada rata-rata 3,50 dengan kriteria jawaban baik, hal ini disebabkan karyawan merasa takut salah mengungkapkan sesuatu kepada manajer dan belum memahami keinginan pelanggan dalam berinteraksi. Kemudian pada indikator pelanggan dapat berkomunikasi dengan baik kepada anda berada pada rata-rata 3,53 dengan kriteria jawaban baik, hal ini disebabkan masih terdapat pelanggan yang tidak sabar menunggu pesanannya selesai.

Untuk dimensi pesan pada indikator manajer dapat memberikan instruksi kerja dengan jelas kepada anda berada pada rata-rata 3,50 dengan kriteria jawaban baik, hal ini disebabkan masih terdapat beberapa karyawan yang belum memahami instruksi kerja secara menyeluruh. Pada indikator anda dapat menyampaikan keluhan kerja kepada manajer secara leluasa berada pada rata-rata 3,60 dengan kriteria jawaban baik, hal ini disebabkan karyawan merasa kurang nyaman ketika berkomunikasi dengan manajer mengenai keluhannya. Selanjutnya pada indikator pelanggan dapat menyampaikan orderan kepada anda dengan baik berada pada rata-rata 3,80 dengan kriteria jawaban baik, hal ini disebabkan pelanggan merasa nyaman dengan pelayanan yang diterimanya.

Untuk dimensi Komunikan pada indikator manajer sebagai penerima pesan anda yang baik berada pada rata-rata 3,63 dengan kriteria jawaban baik, hal ini disebabkan manajer kurang mampu menangani keluh-kesah dari karyawan dan pelanggan. Pada indikator anda sebagai penerima pesan manajer dan pelanggan yang baik berada pada rata-rata 3,70 dengan kriteria jawaban baik, hal ini disebabkan hanya sebagian karyawan mampu melaksanakan instruksi kerja dari manajer dan menerima orderan dari pelanggan. Kemudian pada indikator pelanggan sebagai penerima pesan anda yang baik berada pada rata-rata 3,67 dengan kriteria jawaban baik, hal ini disebabkan orderan yang dipesan sesuai dengan permintaan pelanggan.

Untuk dimensi saluran/media pada indikator manajer dapat berkomunikasi melalui telepon kepada anda dengan jelas berada pada rata-rata 3,60 dengan kriteria jawaban baik, hal ini disebabkan manajer hanya berinteraksi dengan kasir melalui telepon dan akan disampaikan kepada karyawan lainnya oleh kasir itu sendiri. Pada indikator anda dapat berkomunikasi kepada Manajer melalui rapat dengan baik dan tanpa adanya tekanan berada pada rata-rata 3,70 dengan kriteria jawaban baik, hal ini disebabkan manajer mengetahui kemampuan kerja karyawan Café melalui rapat. Selanjutnya pada indikator pelanggan dapat berkomunikasi kepada manajer dalam bentuk surat pengaduan berada pada rata-rata 3,63 dengan kriteria jawaban baik, hal ini disebabkan pelanggan hanya dapat berinteraksi dengan manajer melalui karyawan karena belum disediakannya kotak saran.

Untuk dimensi efek pada indikator pekerjaan yang anda lakukan akan menjadi lebih efektif setelah mendapat instruksi kerja dari manajer berada pada rata-rata 3,60 dengan kriteria jawaban baik, hal ini disebabkan masih terdapat karyawan yang melakukan pelanggaran terhadap peraturan kerja. Pada indikator manajer akan melakukan evaluasi terhadap kinerja karyawannya setelah mendapat catatan keluhan dari anda berada pada rata-rata 3,63 dengan kriteria jawaban baik, hal ini disebabkan karena manajer hanya dapat melakukan evaluasi terhadap kinerja karyawannya saat rapat berlangsung. Kemudian pada indikator anda melakukan pelayanan dengan cepat dan tepat setelah menerima orderan dari pelanggan berada pada ratarata 3,50 dengan kriteria jawaban baik, hal ini disebabkan masih terdapat pelanggan yang mengeluh mengenai pelayanan yang diterima.

2) Gambaran Disiplin Kerja Pada Café Kopi Massa Koktong LIM MING Pematangsiantar 
Dari hasil analisa, dapat dilihat bahwa sebagian besar responden berpendapat disiplin kerja pada tahap yang baik. Untuk dimensi frekuensi kehadiran pada indikator jam masuk kerja anda sesuai jadwal berada pada 3,63 dengan kriteria jawaban baik, hal ini disebabkan karyawan masuk kerja tepat waktu. Pada indikator jam pulang kerja anda sesuai jadwal berada pada rata-rata 3,53 dengan kriteria jawaban baik, hal ini disebabkan jam pulang kerja karyawan terkadang dapat melebihi jadwal pulang kerja yang semestinya. Selanjutnya pada indikator anda hadir bekerja setiap hari, kecuali off day berada pada rata-rata 3,73 dengan kriteria jawaban baik, hal ini disebabkan hanya sebagian karyawan yang mengambil jadwal off day bersamaan dengan off day rekan kerjanya.

Untuk dimensi tingkat kewaspadaan pada indikator anda selalu memperhatikan kondisi peralatan makan pelanggan berada pada rata-rata 3,63 dengan kriteria jawaban baik, hal ini disebabkan kondisi peralatan makan tersusun dengan rapi. Pada indikator anda selalu memperhatikan kondisi bahan baku makanan dan minuman berada pada rata-rata 3,63 dengan kriteria jawaban baik disebabkan masih terdapat karyawan yang kurang memperhatikan kondisi bahan baku persediaan sebelum digunakan Kemudian pada indikator anda selalu memperhatikan tata cara menghidangkan orderan di atas meja tamu dengan baik berada pada rata-rata 3,50 dengan kriteria jawaban baik disebabkan masih terdapat karyawan yang belum mampu menghidangkan pesanan dengan baik kepada pelanggan.

Untuk dimensi ketaatan pada standar kerja pada indikator anda dapat menyelesaikan pekerjaan sesuai dengan standar jam kerja berada pada rata-rata 3,60 dengan kriteria jawaban baik, hal ini disebabkan karyawan mampu menyelesaikan pekerjaannya dengan cepat. Pada indikator anda dapat menerapkan prosedur kerja sesuai standar kerja berada pada ratarata 3,77 dengan kriteria jawaban baik, hal ini disebabkan karyawan dapat bekerja sesuai prosedur kerja. Selanjutnya pada indikator anda dapat melaksanakan pelayanan sesuai dengan standar operational procedure yang berlaku berada pada rata-rata 3,57 dengan kriteria jawaban baik, hal ini disebabkan masih terdapat karyawan yang melayani tamu dengan wajah tanpa senyuman karyawan melayani pelanggan dengan ramah dan sopan.

Pada dimensi ketaatan pada peraturan kerja pada indikator anda selalu mengenakan seragam kerja dengan rapi berada pada rata-rata 3,77 dengan kriteria jawaban sangat baik, hal ini disebabkan karyawan rutin bekerja mengenakan seragam kerja sesuai jadwal. Pada indikator anda memiliki penampilan diri yang sesuai dengan aturan kerja berada pada rata-rata 3,70 dengan kriteria jawaban baik, hal ini disebabkan karyawan berpenampilan rapi setiap bekerja. Selanjutnya pada indikator manajer menegur anda ketika anda melanggar aturan kerja berada pada rata-rata 3,93 dengan kriteria jawaban baik, hal ini disebabkan manajer bersikap adil ketika menegur karyawan yang melakukan kesalahan.
Untuk dimensi etika kerja pada indikator anda menghormati manajer Café berada pada rata-rata 4,00 dengan kriteria jawaban baik, hal ini disebabkan manajer sangat disegani oleh karyawannya. Pada indikator anda menghargai rekan kerja anda sebagai sesama karyawan Café berada pada rata-rata 3,77 dengan kriteria jawaban baik, hal ini disebabkan masih terdapat beberapa karyawan yang belum mampu bersikap profesional dalam bekerja. Kemudian pada indikator anda bersikap ramah kepada seluruh pelanggan Café berada pada rata-rata 3,50 dengan kriteria jawaban baik, hal ini disebabkan masih ada karyawan yang kurang peduli terhadap pelanggan.

Untuk dimensi sanksi pelanggaran disiplin pada indikator manajer akan memberikan teguran, apabila ada karyawan yang melakukan pelanggaran ringan berada pada rata-rata 3,93 dengan kriteria jawaban baik, hal ini disebabkan manager tidak sungkan menegur karyawan yang melakukan kesalahan. Pada indikator manajer akan memberikan Surat Peringatan (SP) pertama hingga ketiga, apabila ada karyawan yang melakukan pelanggaran sedang berada pada rata-rata 3,73 dengan kriteria jawaban baik, hal ini disebabkan karyawan tidak merasa jera terhadap kesalahan yang telah dilakukannya. Selanjutnya pada indikator manajer akan melakukan Pemutusan Hubungan Kerja (PHK), apabila ada karyawan yang melakukan kesalahan yang fatal berada pada rata-rata 3,53 dengan kriteria jawaban baik, hal ini disebabkan masih terdapat karyawan yang melakukan kesalahan fatal.

\section{3) Gambaran Kinerja Karyawan Pada Café Kopi}

Massa Koktong LIM MING Pematangsiantar Dari hasil analisa, dapat dilihat bahwa sebagian besar responden berpendapat kinerja karyawan pada tahap yang cukup baik. Untuk dimensi kuantitas pada indikator kemampuan anda dalam mencapai target penjualan setiap bulan berada pada rata-rata 3,27 dengan kriteria jawaban cukup baik, hal ini disebabkan masih terdapat beberapa karyawan yang belum memahami target penjualan. Pada indikator kemampuan anda dalam mengelola biaya secara efisien melalui inisiatif anda dalam menghemat energi listrik berada pada rata-rata 3,17 dengan kriteria jawaban cukup baik, hal ini disebabkan kurangnya inisiatif dari setiap karyawan. Kemudian pada indikator kemampuan manajer anda dalam menyesuaikan harga jual Café terhadap harga jual Café lainnya berada pada rata-rata 3,33 dengan kriteria jawaban cukup baik, hal ini disebabkan manajer mampu menyesuaikan harga jual produk yang ada.

Untuk dimensi kualitas pada indikator kemampuan anda dalam mengutamakan pelayanan berada pada rata-rata 3,37 dengan kriteria jawaban cukup baik, hal ini disebabkan masih ada karyawan yang kurang serius dalam melayani tamu. Pada indikator kemampuan anda dalam bekerja menggunakan inisiatif sendiri berada pada rata-rata 3,43 dengan kriteria jawaban baik, hal ini disebabkan karyawan mampu melakukan pekerjaannya masing- 
masing. Selanjutnya pada indikator kemampuan anda dalam menunjukkan tanggungjawab anda dalam bekerja berada pada rata-rata 3,27 dengan kriteria jawaban cukup baik, hal ini disebabkan pekerjaan yang dilakukan karyawan dapat selesai dengan baik.

Untuk dimensi ketepatan waktu pada indikator kemampuan anda dalam mematuhi ketetapan waktu masuk kerja berada pada rata-rata 3,13 dengan kriteria jawaban sangat baik, hal ini disebabkan setiap karyawan dapat datang lebih awal disaat jam masuk kerja. Pada indikator kemampuan anda dalam melaksanakan pekerjaan secara tepat waktu berada pada rata-rata 3,23 dengan kriteria jawaban cukup baik, hal ini disebabkan setiap karyawan melakukan pekerjaan dengan benar. Kemudian pada indikator kemampuan anda dalam menggunakan waktu kerja secara efektif berada pada rata-rata 3,23 dengan kriteria jawaban cukup baik, hal ini disebabkan karyawan mampu melakukan pekerjaan secara efektif.

Untuk dimensi kehadiran pada indikator kemampuan anda dalam mematuhi aturan kerja mengenai kehadiran berada pada rata-rata 3,33 dengan kriteria jawaban cukup baik, hal ini disebabkan karyawan patuh terhadap peraturan jadwal kerja. Pada indikator kemampuan anda dalam memberikan surat keterangan apabila tidak hadir bekerja berada pada rata-rata 3,43 dengan kriteria jawaban baik, hal ini disebabkan masih terdapat beberapa karyawan yang absen tanpa pemberitahuan. Selanjutnya pada indikator kemampuan manajer dalam memberikan sanksi terhadap karyawan yang sering tidak hadir bekerja berada pada rata-rata 3,47 dengan kriteria jawaban baik, hal ini disebabkan manajer dengan adil memberikan sanksi terhadap karyawan yang absen bekerja.

Untuk dimensi sikap kooperatif pada indikator kemampuan manajer dalam bekerjasama dengan karyawan Café berada pada rata-rata 3,37 dengan kriteria jawaban cukup baik, hal ini disebabkan manajer tidak sungkan bekerja sama dengan karyawannya. Pada indikator kemampuan anda dalam bekerjasama dengan rekan kerja anda berada pada rata-rata 3,37 dengan kriteria jawaban cukup baik, hal ini disebabkan masih terdapat karyawan yang belum mampu bekerja sama dengan rekan kerjanya. Kemudian pada indikator kemampuan anda dalam bekerjasama dengan pelanggan Café berada pada rata-rata 3,53 dengan kriteria jawaban baik, hal ini disebabkan para karyawan mampu bekerja sama dengan pelanggan.

\section{b. Deskriptif Kuantitatif \\ 1) Regresi Linear Berganda}

Analisa regresi linier berganda digunakan untuk mengetahui pengaruh variabel bebas $(\mathrm{X})$ dan variabel terikat (Y), dimana $\mathrm{X}$ adalah komunikasi, disiplin kerja dan Y adalah kinerja karyawan. Maka dilakukan perhitungan mengunakan program aplikasi SPSS untuk memperoleh nilai $a$ dan $b$ dengan notasi sebagai berikut:
Tabel 3

Hasil Regresi Linier Berganda Coefficients $^{\mathrm{a}}$

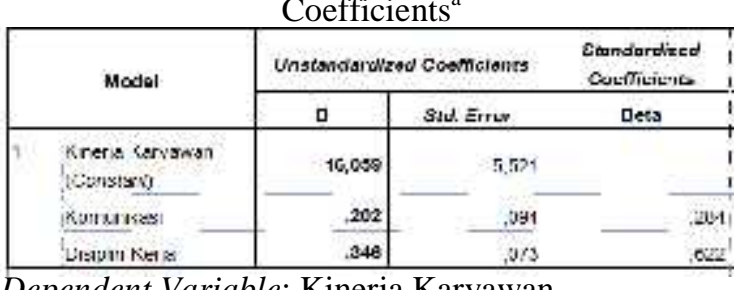

Dependent Variable: Kinerja Karyawan

Sumber: hasil pengolahan data dengan SPSS versi 20

Berdasarkan hasil pengolahan data pada tabel diperoleh model persamaan $\hat{\mathrm{Y}}=16,059+0,202 \mathrm{X}_{1}+$ $0,346 \mathrm{X}_{2}$, artinya terdapat pengaruh yang positif antara variabel komunikasi $\left(\mathrm{X}_{1}\right)$ dan disiplin kerja $\left(\mathrm{X}_{2}\right)$ terhadap variabel kinerja karyawan (Y) pada Café Kopi Massa Koktong LIM MING Pematangsiantar.

\section{2) Koefisien Korelasi dan Koefisien Determinasi}

Hasil koefisien korelasi dan koefisien determinasi dapat dilihat pada tabel berikut ini: Tabel 4

Hasil Koefisien Korelasi dan Determinasi

\begin{tabular}{|c|c|c|c|c|}
\hline \multicolumn{5}{|c|}{ Model Summary ${ }^{\text {b }}$} \\
\hline Madel & $R$ & $\begin{array}{c}R \\
\text { Squars }\end{array}$ & $\begin{array}{l}\text { Adjusred } R \\
\text { squore }\end{array}$ & Stod. Error of the Estimate \\
\hline 1 & $77 \theta^{x}$ & 606 & bil & $124:$ \\
\hline
\end{tabular}

Kerja)

b. Dependent Variabel: (Kinerja Karyawan)

Sumber: hasil pengolahan data dengan SPSS versi 20

Dari hasil koefisien korelasi pada tabel di atas diperoleh nilai $\mathrm{r}=0,778$, yang artinya terdapat hubungan yang sedang dan positif antara komunikasi, disiplin kerja dan kinerja karyawan pada Café Kopi Massa Koktong LIM MING Pematangsiantar, sesuai dengan kriteria tingkat hubungan pada tabel 2. Kemudian diperoleh nilai koefisien determinasi ( $\mathrm{R}$ Square) $=0,606$, artinya baik tidaknya kinerja karyawan (Y) pada Café Kopi Massa Koktong LIM MING Pematangsiantar sebesar $60,6 \%$ dapat dijelaskan oleh komunikasi dan disiplin kerja, sedangkan sisanya sebesar 39,4\% dipengaruhi oleh faktor lain seperti budaya organisasi, kompensasi, gaya kepemimpinan, lingkungan kerja, dan lain sebagainya yang tidak dibahas dalam penelitian ini.

\section{3) Uji Hipotesis}

\section{a) Uji Simultan (Uji F)}

Pengujian ini dilakukan secara simultan yaitu dilakukan untuk menentukan diterima atau ditolaknya hipotesis, pengujian hipotesis dilakukan untuk mengetahui apakah variabel Komunikasi dan Disiplin kerja yang diuji berpengaruh terhadap Kinerja karyawan. Jika $\mathrm{F}_{\text {hitung }}>\mathrm{F}_{\text {tabel }}$ atau tingkat signifikansi $\leq 0,05$ maka $\mathrm{H}_{0}$ ditolak. 
Tabel 5

Hasil Uji Simultan (Uji F) ANOVA ${ }^{a}$

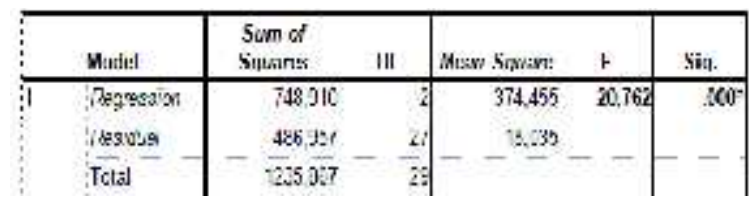

a. Dependent Variabel: Kinerja Karyawan

b. Predictors: (Constant), Disiplin Kerja, Komunikasi

Sumber: hasil pengolahan data dengan SPSS versi 20 Berdasarkan tabel di atas diperoleh nilai $F_{\text {hitung }}$ sebesar 20,762 > $\mathrm{F}_{\text {tabel }}(0,05 ; 2$ vs 27) dengan $\mathrm{df}=\mathrm{n}$ $\mathrm{k}-1 \quad(30-2-1=27)$ sebesar 3,35 atau taraf signifikan $0,000<\alpha 0,05$ maka $\mathrm{H}_{0}$ ditolak, artinya komunikasi dan disiplin kerja berpengaruh positif dan signifikan terhadap kinerja karyawan pada Café Kopi Massa Koktong LIM MING Pematangsiantar secara simultan.

\section{b) Uji Parsial (Uji t)}

Pengujian ini dilakukan secara parsial yaitu dilakukan untuk menentukan diterima atau ditolaknya hipotesis, pengujian hipotesis dilakukan untuk mengetahui apakah variabel Komunikasi dan Disiplin kerja yang diuji berpengaruh terhadap Kinerja karyawan. Jika $t_{\text {hitung }}>t_{\text {tabel }}$ atau tingkat signifikansi $\leq 0,05$ maka $\mathrm{H}_{0}$ ditolak. Tabel 6

Perkiraan Nilai $t_{\text {hitung }}$

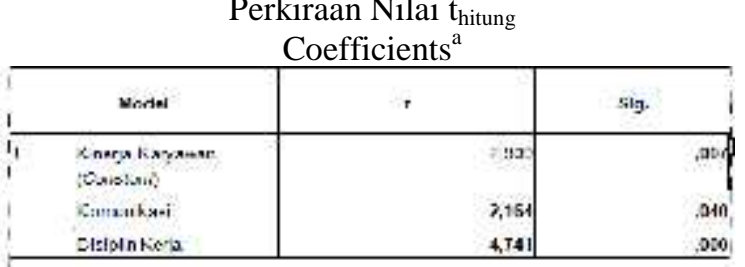

a. Dependent Variabel: Kinerja Karyawan

Sumber: hasil pengolahan data dengan SPSS versi 20

Berdasarkan tabel di atas diperoleh nilai $t_{\text {hitung }}$ pada variabel komunikasi $\left(\mathrm{X}_{1}\right)$ sebesar 2,164 $>\mathrm{t}_{\text {tabel }}$ dengan df = n-k-1 (30-2-1=27) sebesar 2,05183 atau taraf signifikan $0,040<\alpha 0,05$ maka $\mathrm{H}_{0}$ ditolak, artinya komunikasi berpengaruh positif dan signifikan terhadap kinerja karyawan pada Café Kopi Massa Koktong LIM MING Pematangsiantar. Variabel disiplin kerja $\left(\mathrm{X}_{2}\right) \mathrm{t}_{\text {hitung }}$ sebesar 4,741 $>\mathrm{t}_{\text {tabel }}$ dengan df = n-k-1 (30-2-1=27) sebesar 2,05183 atau taraf signifikan $0,000<\alpha 0,05$ maka $\mathrm{H}_{0}$ ditolak, artinya komunikasi dan disiplin kerja berpengaruh positif dan signifikan terhadap kinerja karyawan pada Café Kopi Massa Koktong LIM MING Pematangsiantar.

\section{Evaluasi}

\section{a. Komunikasi Pada Café Kopi Massa Koktong}

\section{LIM MING Pematangsiantar}

Untuk dimensi komunikator pada indikator manajer dapat berkomunikasi dengan baik kepada anda berada pada rata-rata 3,57 dengan kriteria jawaban baik, hal ini disebabkan hanya sesekali manajer dapat berinteraksi dengan karyawan, untuk mengatasi hal ini sebaiknya manajer melakukan komunikasi informal kepada setiap karyawan.

Pada indikator anda dapat berkomunikasi dengan baik kepada manajer dan pelanggan berada pada rata-rata 3,50 dengan kriteria jawaban baik, hal ini disebabkan karyawan merasa takut salah mengungkapkan sesuatu kepada manajer dan belum memahami keinginan pelanggan dalam berinteraksi, untuk mengatasi hal ini sebaiknya karyawan memberanikan diri untuk berinteraksi dengan manajer jika ada hal yang mengganggu pikirannya dengan santun dan belajar mengahadapi pelanggan dengan penuh kesabaran sehingga karyawan tersebut dapat memahami keinginan pelanggan.

Kemudian pada indikator pelanggan dapat berkomunikasi dengan baik kepada anda berada pada rata-rata 3,53 dengan kriteria jawaban baik, hal ini disebabkan masih terdapat pelanggan yang tidak sabar menunggu pesanannya selesai, untuk mengatasi hal ini sebaiknya karyawan dapat memberikan senyumannya ketika menyampaikan waktu tunggu pesanan dengan alasan yang tepat.

Untuk dimensi pesan pada indikator manajer dapat memberikan instruksi kerja dengan jelas kepada anda berada pada rata-rata 3,50 dengan kriteria jawaban baik, hal ini disebabkan masih terdapat beberapa karyawan yang belum memahami instruksi kerja secara menyeluruh, untuk mengatasi hal ini sebaiknya manajer menjelaskan sebuah instruksi kerja dengan cara yang berbeda kepada karyawan yang sulit memahami penjelasan sebelumnya supaya karyawan tersebut dapat memahami instruksi kerja setelah dijelaskan kembali oleh manajer.

Pada indikator anda dapat menyampaikan keluhan kerja kepada manajer secara leluasa berada pada rata-rata 3,60 dengan kriteria jawaban baik, hal ini disebabkan karyawan merasa kurang nyaman ketika berkomunikasi dengan manajer mengenai keluhannya, untuk mengatasi hal ini sebaiknya manajer berinteraksi setiap hari kepada setiap karyawan tanpa pandang buluh, sehingga karyawan dapat merasa nyaman dengan percakapannya dengan manajer.

Untuk dimensi saluran/media pada indikator manajer dapat berkomunikasi melalui telepon kepada anda dengan jelas berada pada rata-rata 3,60 dengan kriteria jawaban baik, hal ini disebabkan manajer hanya berinteraksi dengan kasir melalui telepon dan akan disampaikan kepada karyawan lainnya, untuk mengatasi hal ini sebaiknya manajer memberikan kesempatan kepada karyawan lainnya untuk menerima telepon dari manajer disaat memberikan suatu pekerjaan.

Untuk dimensi efek pada indikator pekerjaan yang anda lakukan akan menjadi lebih efektif setelah mendapat instruksi kerja dari manajer berada pada rata-rata 3,60 dengan kriteria jawaban baik, hal ini disebabkan masih terdapat karyawan yang belum mampu mematuhi peraturan kerja, untuk mengatasi hal ini sebaiknya manajer memberikan peraturan yang adil secara tertulis. 
Kemudian pada indikator anda melakukan pelayanan dengan cepat dan tepat setelah menerima orderan dari pelanggan berada pada rata-rata 3,50 dengan kriteria jawaban baik, hal ini disebabkan masih terdapat beberapa karyawan yang kurang mampu untuk melakukan pelayanan dengan cepat dan tepat, untuk mengatasi hal ini sebaiknya manajer melakukan pelatihan kepada setiap karyawannya mengenai pelayanan supaya setiap karyawan dapat melakukan pelayanan sesuai SOP (Standart Operational Procedure) yang berlaku.

\section{b. Disiplin Kerja Pada Café Kopi Massa Koktong LIM MING Pematangsiantar}

Untuk dimensi frekuensi kehadiran pada indikator jam masuk kerja anda sesuai jadwal berada pada rata-rata 3,63 dengan kriteria jawaban baik, hal ini disebabkan masih terdapat beberapa karyawan yang jam datang bekerja melebihi jadwal masuk kerja yang semestinya, untuk mengatasi hal ini sebaiknya manajer menyediakan mesin daftar hadir supaya jam masuk dan pulang kerja setiap karyawan dapat diketahui dengan mudah.

Kemudian pada indikator jam pulang kerja anda sesuai jadwal berada pada rata-rata 3,53 dengan kriteria jawaban baik, hal ini disebabkan jam pulang kerja karyawan terkadang dapat melebihi jadwal pulang kerja yang semestinya, untuk mengatasi hal ini sebaiknya manajer menerapkan jam pulang kerja sesuai jadwal pulang yang semestinya, sehingga karyawan memiliki waktu yang cukup untuk beristirahat.

Untuk dimensi tingkat kewaspadaan pada indikator anda selalu memperhatikan kondisi peralatan makan pelanggan berada pada rata-rata 3,63 dengan kriteria jawaban baik, hal ini disebabkan kondisi peralatan makan tersusun dengan kurang rapi, untuk mengatasi hal ini sebaiknya karyawan membersihkan rak peralatan makan dan menyusun piring beserta gelas yang ada dengan rapi agar setiap karyawan dapat memilih dengan mudah peralatan makan yang baik atau tidak baik untuk digunakan.

Pada indikator anda selalu memperhatikan kondisi bahan baku makanan dan minuman berada pada rata-rata 3,63 dengan kriteria jawaban baik disebabkan masih terdapat karyawan yang kurang memperhatikan kondisi bahan baku persediaan sebelum digunakan, untuk mengatasi hal ini sebaiknya manajer menetapkan seorang karyawan secara bergantian yang ditugaskan untuk mengecek keadaan bahan baku saat akan digunakan supaya kondisi bahan baku selalu segar untuk digunakan.

Kemudian pada indikator anda selalu memperhatikan tata cara menghidangkan orderan di atas meja tamu dengan baik berada pada rata-rata 3,50 dengan kriteria jawaban baik disebabkan masih terdapat karyawan yang belum mampu menghidangkan pesanan dengan baik kepada pelanggan, untuk mengatasi hal ini sebaiknya manajer memberikan pelatihan mengenai tata cara penghidangan pesanan di atas meja tamu, sehingga tidak terjadi kelalaian dalam menata hidangan di atas meja tamu.
Untuk dimensi ketaatan pada standar kerja pada indikator anda dapat menyelesaikan pekerjaan sesuai dengan standar jam kerja berada pada rata-rata 3,60 dengan kriteria jawaban baik, hal ini disebabkan karyawan belum mampu menyelesaikan pekerjaannya dengan cepat, untuk mengatasi hal ini sebaiknya manajer melatih kecepatan karyawan dalam melaksanakan pekerjaannya agar karyawan mampu melayani dengan cepat dan tepat.

Kemudian pada indikator anda dapat melaksanakan pelayanan sesuai dengan standar operational procedure yang berlaku berada pada rata-rata 3,57 dengan kriteria jawaban baik, hal ini disebabkan masih terdapat karyawan yang melayani pelanggan dengan wajah tanpa senyuman, untuk mengatasi hal ini sebaiknya manajer harus menegaskan kepada setiap karyawan untuk tetap tersenyum dan ramah kepada setiap pelanggan, sehingga pelanggan merasa puas dengan pelayanan yang disediakan.

Untuk dimensi etika kerja pada indikator anda bersikap ramah kepada seluruh pelanggan Café berada pada rata-rata 3,50 dengan kriteria jawaban baik, hal ini disebabkan masih ada karyawan yang kurang peduli terhadap pelanggan, untuk mengatasi hal ini sebaiknya manajer memberikan teguran yang tegas sebelum memberikan peringatan kepada setiap karyawan supaya karyawan memahami tanggungjawabnya dalam bekerja.

Untuk dimensi sanksi pelanggaran disiplin pada indikator manajer akan melakukan Pemutusan Hubungan Kerja (PHK), apabila ada karyawan yang melakukan kesalahan yang fatal berada pada ratarata 3,53 dengan kriteria jawaban baik, hal ini disebabkan masih terdapat karyawan yang melakukan kesalahan fatal, untuk mengatasi hal ini sebaiknya manajer berusaha menegur karyawan tersebut dengan tegas hingga dikeluarkannya surat peringatan ketiga sebelum melakukan Pemutusan Hubungan Kerja (PHK) agar tidak terjadi tuntutan pekerja dikemudian harinya.

\section{c. Kinerja Karyawan pada Café Kopi Massa \\ Koktong LIM MING Pematangsiantar}

Untuk dimensi kuantitas pada indikator kemampuan anda dalam mencapai target penjualan setiap bulan berada pada rata-rata 3,27 dengan kriteria jawaban cukup baik, hal ini disebabkan masih terdapat beberapa karyawan yang belum memahami target penjualan, untuk mengatasi hal ini sebaiknya manajer menjelaskan mengenai target penjualan pada saat rapat berlangsung dengan jelas kepada karyawannya supaya karyawan dapat memahami kuantitas kinerja yang harus dicapai.

Pada indikator kemampuan anda dalam mengelola biaya secara efisien melalui inisiatif sendiri berada pada rata-rata 3,17 dengan kriteria jawaban cukup baik, hal ini disebabkan kurangnya inisiatif dari setiap karyawan, untuk mengatasi hal ini sebaiknya setiap manajer memberikan arahan yang tepat kepada karyawan untuk menggunakan inisiatif masing-masing dalam bekerja supaya 
karyawan mampu memotivasi diri sendiri dalam melakukan pekerjaannya.

Untuk dimensi kualitas pada indikator kemampuan anda dalam menunjukkan tanggungjawab anda dalam bekerja berada pada ratarata 3,27 dengan kriteria jawaban cukup baik, hal ini disebabkan pekerjaan yang dilakukan karyawan dapat selesai dengan baik, untuk mengatasi hal ini sebaiknya manajer menegur dan memotivasi karyawan untuk lebih bertanggungjawab terhadap pekerjaannya, sehingga karyawan dapat termotivasi oleh setiap teguran yang diberikan kepadanya.

Untuk dimensi ketepatan waktu pada indikator kemampuan anda dalam mematuhi ketetapan waktu masuk kerja berada pada rata-rata 3,13 dengan kriteria jawaban sangat baik, hal ini disebabkan masih terdapat beberapa karyawan yang terlambat masuk kerja, untuk mengatasi hal ini sebaiknya manajer menyediakan mesin daftar absen dan memberikan sanksi ringan berupa pemotongan gaji untuk setiap keterlambatan supaya setiap karyawan dapat mematuhi jadwal kerja yang telah ditetapkan

Pada indikator kemampuan anda dalam melaksanakan pekerjaan secara tepat waktu berada pada rata-rata 3,23 dengan kriteria jawaban cukup baik, hal ini disebabkan setiap karyawan melakukan pekerjaan dengan benar, untuk mengatasi hal ini sebaiknya manajer memberikan pelatihan yang sesuai dengan jabatan karyawan tersebut supaya karyawan dapat memahami pekerjaan yang harus dilakukan dengan baik dan benar.

Kemudian pada indikator kemampuan anda dalam menggunakan waktu kerja secara efektif berada pada rata-rata 3,23 dengan kriteria jawaban cukup baik, hal ini disebabkan karyawan belum mampu melakukan pekerjaan secara efektif, untuk mengatasi hal ini sebaiknya manajer menegur secara bijak terhadap karyawan yang kurang efektif dalam bekerja, sehingga karyawan dapat menyadari tanggungjawabnya dalam bekerja.

\section{KESIMPULAN DAN SARAN}

\section{Kesimpulan}

a. Hasil analisis deskriptif kualitatif tentang komunikasi berdasarkan dimensi komunikator, pesan, komunikan, saluran/media, dan efek memperoleh rata-rata jawaban keseluruhan 3,61 dengan kriteria jawaban baik. Kemudian nilai rata-rata tertinggi sebesar 3,80 dengan kriteria nilai baik pada dimensi komunikan dengan indikator Pelanggan dapat menyampaikan orderan kepada Anda dengan baik. Sedangkan, nilai rata-rata terendah sebesar 3,50 dengan kriteria jawaban baik pada dimensi komunikator dengan indikator Anda dapat berkomunikasi dengan baik kepada Manajer dan pelanggan. Pada dimensi pesan dengan indikator Manajer dapat memberikan instruksi kerja dengan jelas kepada Anda. Pada dimensi efek dengan indikator Anda melakukan pelayanan dengan cepat dan tepat setelah menerima orderan dari pelanggan b. Hasil analisis deskriptif kualitatif tentang disiplin kerja berdasarkan dimensi frekuensi kehadiran, tingkat kewaspadaan, ketaatan pada standar kerja, ketaatan pada peraturan kerja memperoleh ratarata 3,70 dengan kriteria jawaban baik. Kemudian nilai rata-rata tertinggi sebesar 4,00 dengan kriteria jawaban baik pada dimensi etika kerja pada standar kerja pada indikator Anda menghormati manajer Café dan nilai terendah sebesar 3,50 dengan kriteria jawaban baik pada dimensi tingkat kewaspadaan dengan indikator Anda selalu memperhatikan tata cara menghidangkan orderan di atas meja tamu dengan baik.

c. Hasil analisis deskriptif kualitatif tentang kinerja karyawan berdasarkan dimensi kuantitas, kualitas, ketepatan waktu, kehadiran di tempat kerja, dan sikap kooperatif memperoleh rata-rata sebesar 3,33 dengan kriteria jawaban cukup baik dengan nilai rata-rata tertinggi sebesar 3,53 dengan kriteria jawaban baik pada dimensi sikap koperatif dengan indikator Kemampuan anda dalam bekerjasama dengan pelanggan Café dan nilai rata-rata terendah sebesar 3,13 dengan kriteria jawaban cukup baik pada dimensi ketepatan waktu dengan indikator Kemampuan Anda dalam mematuhi ketetapan waktu masuk kerja.

d. Hasil analisis persamaan regresi linear berganda yang dihitung melalui program SPSS versi 20 sebagai persamaan $\hat{Y}=16,059+0,202 \mathrm{X}_{1}+$ $0,346 \mathrm{X}_{2}$, artinya terdapat pengaruh yang positif antara variabel komunikasi $\left(\mathrm{X}_{1}\right)$ dan disiplin kerja $\left(\mathrm{X}_{2}\right)$ terhadap variabel kinerja karyawan $(\mathrm{Y})$ pada Café Kopi Massa Koktong LIM MING Pematangsiantar.

e. Hasil analisis koefisien korelasi dan koefisien determinasi, diperoleh korelasi nilai $r=0,778$, yang artinya terdapat hubungan yang sedang dan positif antara komunikasi, disiplin kerja terhadap kinerja karyawan pada Café Kopi Massa Koktong LIM MING Pematangsiantar. Diperoleh nilai koefisien determinasi (KD) 0,606, artinya baik tidaknya kinerja karyawan pada Café Kopi Massa Koktong LIM MING Pematangsiantar sebesar $60,6 \%$ dapat dijelaskan oleh komunikasi dan disiplin kerja, sedangkan sisanya sebesar $39,4 \%$ dipengaruhi oleh faktor lain seperti budaya organisasi, kompensasi, gaya kepemimpinan, lingkungan kerja, dan lain sebagainya yang tidak dibahas dalam penelitian ini.

f. Hasil uji hipotesis secara simultan dengan uji $\mathrm{F}$ diperoleh nilai $F_{\text {hitung }}$ sebesar 20,762 $>F_{\text {tabel }}(0,05$ ; 2 vs 27) dengan $\mathrm{df}=\mathrm{n}-\mathrm{k}-1 \quad(30-2-1=27)$ sebesar 3,35 atau taraf signifikan $0,000<\alpha 0,05$ maka $\mathrm{H}_{0}$ ditolak, artinya komunikasi dan disiplin kerja berpengaruh positif dan signifikan terhadap kinerja karyawan pada Café Kopi Massa Koktong LIM MING Pematangsiantar secara simultan.

g. Hasil uji hipotesis secara parsial dengan uji $\mathrm{t}$ pada komunikasi $\left(\mathrm{X}_{1}\right)$ sebesar 2,164 $>\mathrm{t}_{\text {tabel }}$ 
dengan $\mathrm{df}=\mathrm{n}-\mathrm{k}-1 \quad(30-2-1=27)$ sebesar 2,05183 atau taraf signifikan $0,040<\alpha 0,05$ maka $\mathrm{H}_{0}$ ditolak, artinya komunikasi berpengaruh positif dan signifikan terhadap kinerja karyawan pada Café Kopi Massa Koktong LIM MING Pematangsiantar. Variabel disiplin kerja $\left(\mathrm{X}_{2}\right)$ $\mathrm{t}_{\text {hitung }}$ sebesar 4,741 $>\mathrm{t}_{\text {tabel }}$ dengan $\mathrm{df}=\mathrm{n}-\mathrm{k}-1$ (302-1=27) sebesar 2,05183 atau taraf signifikan $0,000<\alpha 0,05$ maka $\mathrm{H}_{0}$ ditolak, artinya komunikasi dan disiplin kerja berpengaruh positif dan signifikan terhadap kinerja karyawan pada Café Kopi Massa Koktong LIM MING Pematangsiantar.

\section{Saran}

a. Untuk meningkatkan komunikasi, Café Kopi Massa Koktong LIM MING Pematangsiantar sebaiknya meningkatkan hubungan komunikasi informal antara manajer dengan karyawan sehingga karyawan dapat leluasa dalam menyampaikan keluhannya dan menyediakan sebuah kotak saran agar pelanggan dapat berpartisipasi memberikan penilaian terhadap pelayanan yang dirasakannya kepada manajer.

b. Untuk meningkatkan disiplin kerja, Café Kopi Massa Koktong LIM MING Pematangsiantar sebaiknya menyediakan mesin absen finger scan dan membuat SOP (Standart Operational Procedure) yang baik agar karyawan lebih disiplin dalam bekerja.

c. Untuk meningkatkan kinerja karyawan, Café Kopi Massa Koktong LIM MING Pematangsiantar sebaiknya manajer memberikan pelatihan dan arahan kepada karyawan agar karyawan mampu memberikan pelayanan secara maksimal kepada pelanggan dan mampu mengikuti peraturan yang sudah ditetapkan oleh manajer.

d. Sehubungan dengan keterbatasan-keterbatasan yang ada pada penulis, penelitian ini masih terdapat kelemahan-kelemahan dan belum dapat mengungkap seluruh variabel yang dapat mempengaruhi kinerja karyawan pada Café Kopi Massa Koktong LIM MING Pematangsiantar. Sebagai bahan masukan untuk penelitian selanjutnya, perlu memperbanyak variabel penelitian, seperti budaya organisasi, kompensasi, gaya kepemimpinan, lingkungan kerja, dan lain sebagainya yang tidak dibahas dalam penelitian ini.

\section{E. DAFTAR PUSTAKA}

As`ad, Moh. 2003. Psikologi Industri Seri Sumber Daya Manusia. Yogyakarta: Liberty.

Davis, Keith. 2008. Perilaku Dalam Organisasi. Edisi Ketujuh. Jakarta: Erlangga.

Dharma, Agus. 2001. Manajemen Sumber Daya Manusia. Jakarta: Erlangga.

Handoko, T. Hani. 2001. Manajemen 2. Yogyakarta: BPFE.

Mondy, Wayne. 2008. Manajemen Sumber Daya Manusia. Jilid Pertama. Edisi Kesepuluh. Jakarta: Erlangga.

........ 2008. Manajemen Sumber Daya Manusia. Jilid Kedua. Edisi Kesepuluh. Jakarta: Erlangga.

Robbins, Stephen P. dan Timothy A. Judge. 2008. Perilaku Organisasi. Edisi Keduabelas. Jakarta: Salemba Empat.

Sastrohadiwiryo, Bejo Siswanto. 2002. Manajemen Tenaga Kerja Indonesia Pendekatan Administratif dan Operasional. Jakarta: PT.Bumi Aksara.

Subarna, Tatang. 2003. Komunikasi Bisnis. Cetakan Keenam. Jakarta: Penerbit Universitas Terbuka.

Sutrisno, Edy. 2011. Manajemen Sumber Daya manusia. Edisi Pertama. Cetakan Ketiga. Jakarta: Kencana.

Tulus, Tu'u. 2004. Peran Disiplin pada Perilaku dan Prestasi Siswa. Jakarta: PT. Grasindo.

Zainal, Veithzal, et. al. 2009. Manajemen Sumber Daya Manusia untuk Perusahaan dari Teori ke Praktik. Edisi Ketiga. Jakarta: PT. Raja Grafindo Persada.

Wursanto. 2005. Dasar-Dasar Ilmu Organisasi. Yogyakarta: Andi. 